\title{
STRUCTURAL BREAKS DAN KETIDAKSTABILAN PERMINTAAN UANG DI INDONESIA
}

\author{
Deviyantini $^{1}$, Iman Sugema ${ }^{2}$, Tony Irawan ${ }^{2}$ \\ ${ }^{1}$ Mahasiswa Program Magister Ilmu Ekonomi, FEM IPB \\ ${ }^{2}$ Staff Pengajar FEM IPB
}

\begin{abstract}
This research aims to identify the sources of instability of the money demand function (M1 and M2) due to structural changes that occur as a result of economic shocks. These shocks are technically shown by the presence of structural breaks in the data and can lead the parameters non-constancy. The instability of the money demand function was analyzed using the Gregory and Hansen test. The source of instability of the money demand was identified using time varying parameter model. This research used quarterly time series data from 1993Q1 to 2013Q4. The results show that the money demand function (M1 dan M2) is not cointegrated (unstable) and the source of the instability is exchange rate variable.
\end{abstract}

Keywords: Stability money demand, Structural breaks, Time varying parameter model

\section{PENDAHULUAN}

Permintaan uang mengacu pada jumlah uang yang dipegang oleh seseorang dalam periode tertentu untuk membiayai transaksi keuangan mereka (Dritsakis, 2012). Jumlah permintaan uang di suatu negara cenderung berfluktuasi dari waktu ke waktu bergantung pada aktivitas dari para pelaku ekonomi di negara tersebut. Pada era globalisasi seperti saat ini, tidak dapat dipungkiri bahwa kuantitas permintaan uang domestik di suatu negara akan dipengaruhi oleh permintaan dari negara-negara lainnya.

Di Indonesia, pertumbuhan uang cenderung bersifat fluktuatif. Kondisi tersebut dapat dilihat pada Gambar 1. Pada tahun 2008, pertumbuhan M1 dan M2 mengalami penurunan yang signifikan, khususnya pertumbuhan M1. Kondisi tersebut merupakan dampak dari terjadinya krisis finansial global yang muncul akibat terjadinya krisis subprime mortgage di Amerika Serikat. Berdasarkan hal tersebut, otoritas moneter perlu mempertimbangkan faktor internasional, disamping faktor domestik sebagai faktor yang memengaruhi kuantitas permintaan uang domestik di negara yang bersangkutan.

Kondisi pasar valuta asing tentunya juga mempunyai pengaruh besar dalam hal tersebut. Oleh karena itu, capital mobility dan currency substitution perlu dipertimbangkan dalam fungsi permintaan uang pada negara dengan sistem perekonomian terbuka (Arango dan Nadiri, 1981; ElShazly, 2016). 


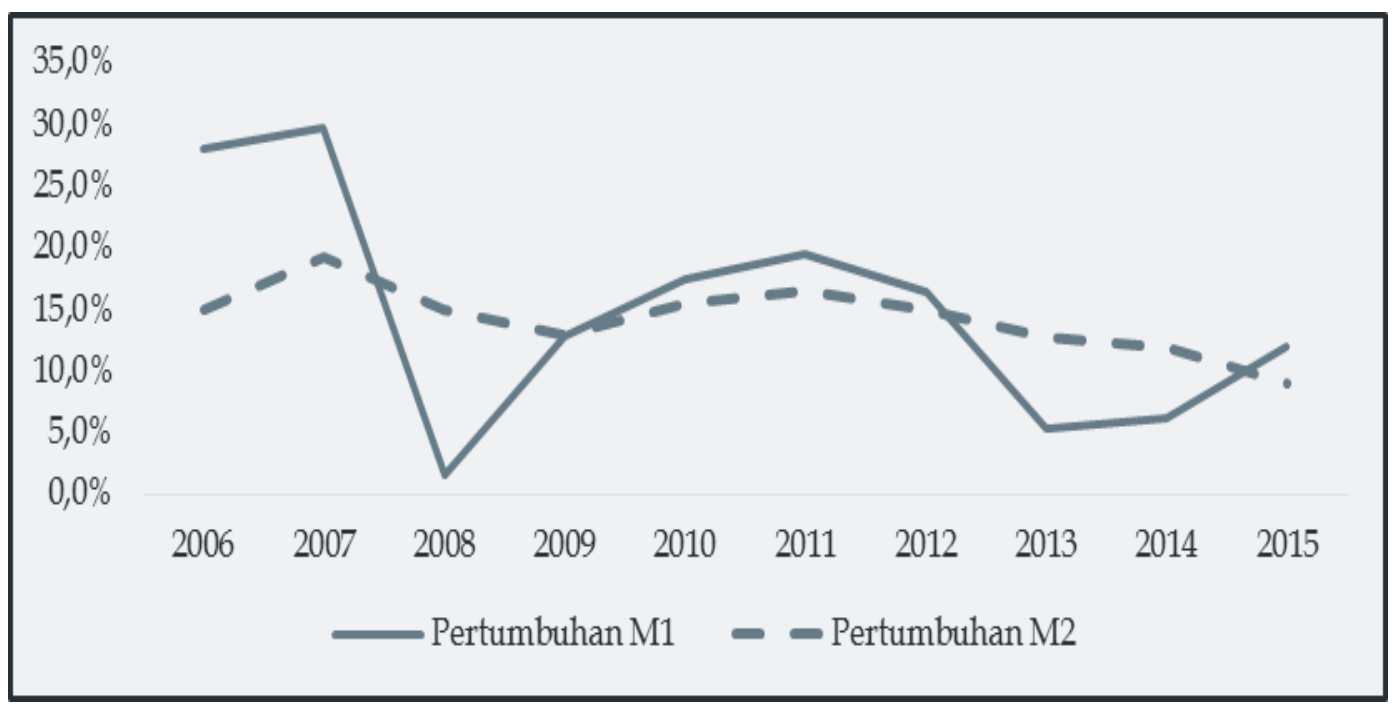

Gambar 1 Pertumbuhan M1 dan M2 di Indonesia

Faktor-faktor yang memengaruhi permintaan uang di suatu negara diantaranya yaitu pendapatan, suku bunga domestik, suku bunga luar negeri, nilai tukar, dan inflasi. Pendapatan merupakan salah satu faktor domestik yang mempunyai hubungan positif terhadap permintaan uang. Hal ini dikarenakan, peningkatan pendapatan domestik akan mempercepat kegiatan transaksi, yang pada akhirnya akan meningkatkan permintaan uang domestik (Arango dan Nadiri, 1981; Narayan, 2007).

Dari sisi suku bunga, pengaruh suku bunga domestik terhadap permintaan uang bergantung pada tipe agregat moneter yang dipilih. Apabila agregat moneter yang digunakan adalah M1, maka hubungannya dengan permintaan uang adalah negatif. Sementara, jika M2 yang dipilih, maka hubungannya adalah positif (El-Shazly, 2016). Selain suku bunga domestik, hubungan antara suku bunga luar negeri, nilai tukar, dan permintaan uang juga saling berkaitan (Arango dan Nadiri, 1981; El-Shazly, 2016).

Dalam capital mobility effect, meningkatnya suku bunga luar negeri atau terdepresiasinya mata uang domestik akan meningkatkan tingkat pengembalian dari aset asing. Oleh karena itu, dampak peningkatan dari suku bunga luar negeri atau depresiasi dari mata uang domestik terhadap permintaan uang akan negatif (ElShazly, 2016). Kondisi ini juga secara tidak langsung menunjukkan kaitan antara permintaan uang dan nilai tukar riil, dimana hubungan keduanya juga negatif. Hubungan negatif antara permintaan uang dan nilai tukar merupakan bukti dari adanya currency substitution (Narayan, 2007).

Inflasi merupakan faktor yang juga penting dalam memengaruhi kuantitas permintaan uang di suatu negara. Inflasi akan selalu menjadi fenomena moneter di negara manapun. Tingkat inflasi biasanya merupakan representasi dari opportunity cost dalam memegang uang domestik relatif terhadap aset-aset fisik, seperti real estate, dan lain-lain (Dreger dan Wolters, 2010; Ericsson, 1998) Sehingga, pada saat inflasi di suatu negara meningkat, maka hal tersebut akan menurunkan permintaan uang di negara tersebut.

Mengingat begitu banyaknya faktor-faktor yang memengaruhi 
permintaan uang pada negara dengan sistem perekonomian terbuka, hal ini tentunya akan memengaruhi kestabilan fungsi permintaan uang. Di sisi lain, stabilitas permintaan uang mempunyai peran penting dalam menentukan kebijakan moneter di suatu negara. Apabila fungsi permintaan uang tidak stabil, maka hal ini akan memengaruhi efektivitas kebijakan moneter di negara tersebut.

Selain karena banyaknya faktor yang memengaruhi fungsi permintaan uang, ketidakstabilan fungsi permintaan uang, secara teknis juga dapat disebabkan oleh perubahan struktural yang terjadi dalam fungsi permintaan uang tersebut. Pada suatu analisis dengan penggunaan periode yang cukup panjang terdapat fenomena maupun peristiwa yang dapat menimbulkan suatu guncangan bagi perekonomian. Guncangan tersebut dapat berasal dari dalam negeri ataupun dunia internasional. Oleh sebab itu, seringkali terdapat breaks pada titik-titik waktu tertentu.

Pandangan tradisional menyatakan bahwa guncangan yang terjadi pada saat ini hanya memiliki efek sementara dan pergerakan dalam jangka panjang pada suatu series tidak berubah oleh guncangan tersebut. Namun, Nelson dan Plosser mencoba menentang pandangan ini dan mengungkapkan pendapatnya bahwa suatu guncangan saat ini memiliki efek permanen dalam jangka panjang terhadap agregat ekonomi makro dan keuangan (Zivot and Andrews, 1992). Oleh karena itu, dalam proses analisis ini peneliti juga akan memperhitungkan keberadaan breaks.

Keberadaan breaks tersebut secara teknis juga dapat mengubah struktur dari suatu series dan menyebabkan parameternya menjadi tidak konstan atau tidak stabil. Ketidakstabilan parameter akibat dari terjadinya perubahan struktural mungkin mencerminkan suatu fenomena struktural seperti (model misspecification, omitted variables, dan measurement error.) dan peristiwa-peristiwa tertentu seperti krisis minyak, krisis moneter, dan kebijakan baru (Farhani, 2012). Oleh karena itu, dalam penelitian ini akan digunakan model time varying parameter (TVP). Model TVP merupakan model yang ditetapkan dalam model state space, dimana pendugaannya dilakukan dengan algoritma Kalman filter (Suwedayana et al., 2016). Hasil dari model TVP akan memberikan informasi mengenai evolusi dari masing-masing koefisien variabel yang terdapat dalam fungsi permintaan uang.

Secara umum tujuan dari penelitian ini adalah untuk mengetahui stabilitas model permintaan uang di Indonesia dengan mempertimbangkan keberadaaan structural breaks. Di sisi lain, penelitian ini juga akan melihat penyebab dari perubahan struktural yang menyebabkan fungsi permintaan unag menjadi tidak stabil.

\section{METODE PENELITIAN}

Penelitian ini menggunakan data sekunder dalam bentuk quarterly time series dari 1993Q1 sampai 2013Q4. Negara yang menjadi objek penelitian adalah Indonesia. Variabel dependen dalam model penelitian ini adalah logaritma dari M1 dan M2 yang menjadi proxy dari permintaan uang di Indonesia. Data M1 merupakan data uang beredar dalam arti sempit meliputi uang kartal yang dipegang oleh masyarakat dan uang giral. Sementara data M2merupakan data uang beredar dalam arti luas yang meliputi M1, uang kuasi dan surat berharga yang diterbitkan oleh sistem moneter yang dimiliki sektor swasta domestik dengan 
sisa jangka waktu sampai dengan satu tahun.

Variabel independen atau variabel penjelas yang digunakan, yaitu variabel pendapatan, suku bunga domestik, suku bunga luar negeri, nilai tukar, dan inflasi. Variabel pendapatan direpresentasikan oleh logaritma Produk Domestik Bruto riil. Sementara itu, suku bunga deposito 3 bulan bank komersial digunakan sebagai proxy untuk suku bunga domestik dan data London Interbank Offered Rate (LIBOR) 3 months digunakan sebagai proxy untuk suku bunga luar negeri. Pada variabel nilai tukar digunakan data real effective exchange rate index yang merupakan jumlah unit mata uang domestik (Rupiah) per unit US dollar dengan mempertimbangkan sejumlah negara mitra dagang Indonesia. Persentase perubahan dalam Indeks Harga Konsumen (IHK) year on year (yoy) menjadi representasi dari variabel inflasi.

Data M1, M2, dan Produk Domesik Bruto riil diperoleh dari Statistik Ekonomi dan Keuangan Indonesia (SEKI) Bank Indonesia. Sementara, data tingkat suku bunga deposito 3 bulan dan IHK berasal dari CEIC Database. Data LIBOR 3-months bersumber dari International Financial Statistic (IFS) dan data real effective exchange rate index diperoleh dari website. Berdasarkan penjelasan tersebut, maka model pemintaan uang yang digunakan dalam penelitian ini dapat dilihat pada persamaan (1). Model ini mengadopsi model penelitian yang digunakan oleh El-Shazly (2016).

$$
m_{t}=\gamma_{0}+\gamma_{1} y_{t}+\gamma_{2} i_{t}^{d}+\gamma_{3} i_{t}^{f}+\gamma_{4} q_{t}+\gamma_{5} \pi_{t}+
$$

Metode yang digunakan dalam penelitian ini adalah uji akar unit dengan menggunakan Zivot and
Andrews Test (ZA Test) dan Augmented Dickey Fuller Test (ADF Test). ZA Test digunakan untuk mengetahui periode breaks yang terjadi pada masing-masing variabel. Sementara itu, untuk menentukan order of integration digunakan ADF Test. Dalam uji kointegrasi untuk mennetukan keseimbangan jangka panjang, dalam penelitian ini akan menggunakan Gregory and Hansen Test (GH Test) yang melibatkan breaks ke dalam proses analisisnya. Apabila, dari hasil uji diperoleh bukti bahwa fungsi permintaan uang tidak memiliki hubungan keseimbangan jangka panjang, atau dengan kata lain tidak stabil, maka akan digunakan state space model, khususnya model Time Varying Parameter (TVP).

\section{Zivot and Andrews Test}

Zivot and Andrews Test merupakan salah satu uji akar unit yang dilakukan dengan pendekatan DickeyFuller. Dalam ZA test, uji akar unit akan dilakukan dengan memper-timbangkan keberadaan dari single break dalam data time series. Zivot dan Andrews (1992) mengembangkan ZA test dari model ADF test. Terdapat tiga model dalam ZA test, yaitu model dengan dummy slope, model dengan dummy intercept, dan model yang memasukkan keduanya (dummy slope dan dummy intercept), masing-masing model dituliskan dalam persamaan di bawah ini.

Model A

$$
\begin{aligned}
& \Delta x_{t}=\mu+\beta t+\gamma D T_{t}+\phi x_{t-1}+ \\
& \sum_{i=1}^{1} d_{i} \Delta x_{t-i}+\varepsilon_{t}
\end{aligned}
$$

Model B

$$
\begin{aligned}
& \Delta x_{t}=\mu+\beta t+\theta D U_{t}+\phi x_{t-1}+ \\
& \sum_{i=1}^{1} d_{i} \Delta x_{t-i}+\varepsilon_{t}
\end{aligned}
$$

Model C 


$$
\begin{aligned}
\Delta x_{t}= & \mu+\beta t+\theta D U_{t}+\gamma D T_{t}+\phi x_{t-1}+ \\
& \sum_{i=1}^{1} d_{i} \Delta x_{t-i}+\varepsilon_{t} \ldots \ldots \ldots \ldots \ldots \ldots \ldots \ldots \ldots \ldots \ldots \ldots \ldots \ldots \ldots
\end{aligned}
$$

Simbol $\Delta$ menunjukkan first difference operator, $\mu$ adalah intersep, dan $t=1$, ..., menunjukkan mengenai data time series. Sementara itu, breaks terjadi pada waktu $1<T_{B}<T$. $D U_{t}$ di dalam model merupakan dummy intercept yang menunjukkan pergeseran di level pada saat periode break $T_{B}$, dimana $D U_{t}$ $=1$ jika $t>T_{B}$, dan 0 untuk lainnya. $D T_{t}$ merupakan dummy slope yang menunjukkan pergeseran trend pada saat periode break $T_{B}$ terjadi. Jika $t>T_{B}$, maka $D T_{t}=t-T_{B}$, dan 0 untuk lainnya. Kriteria penolakan hipotesis nol $(\phi=0)$ adalah pada saat nilai test statistic pada $\phi$ berada di bawah nilai critical value. Dalam penelitian ini, dipilih Model C untuk diterapkan dalam analisis ZA test.

\section{Augmented Dickey Fuller Test}

Augmented Dickey Fuller Test merupakan penyempurnaan dari Dickey Fuller test (DF test) yang telah hadir terlebih dulu dalam pengujian akar unit. $\mathrm{ADF}$ test hadir untuk mengatasi masalah autokorelasi yang terdapat pada DF test yang dibangun oleh Dickey dan Fuller (1979).

$y_{t}=\rho y_{t-1}+e_{t} ; e_{t} \sim N I I D(0,1)$

dimana, $y_{t}$ merupakan variabel yang diamati, $t$ menunjukkan time index, $\rho$ adalah koefisien, sementara $e_{t}$ merupakan error term. Data dikatakan stasioner, apabila $|\rho|>1$, sementara apabila nilai koefisien $|\rho|=1$, maka data tidak stasioner. Model regresi juga bisa dituliskan dalam bentuk:

$$
\begin{aligned}
& \Delta y_{t}=\delta y_{t-1}+e_{t} \\
& \Delta y_{t}=a_{0}+\delta y_{t-1}+e_{t} \ldots \ldots \ldots \ldots \\
& \Delta y_{t}=a_{0}+\delta y_{t-1}+a_{2} t+e_{t}
\end{aligned}
$$

dimana, $\Delta y_{t}$ merupakan first difference operator. Dalam model tersebut, keberadaan akar unit ditandai dengan nilai koefisien $\delta=0$, dimana $\delta \equiv \rho-1$. Perbedaan dari ketiga persamaan regresi di atas adalah, persamaan (6) merupakan pure random walk, persamaan (7) menambahkan intersep atau drift, sementara persamaan (8) memasukkan drift dan time trend (Enders, 2004).

Dengan melalui proses autoregresif, maka diperolehlah model persamaan untuk ADF Test dengan berdasarkan pada tiga persamaan sebelumnya. Persamaan tersebut adalah sebagai berikut (Enders, 2004).

$$
\begin{aligned}
\Delta y_{t}= & \delta y_{t-1}+\sum_{i=2}^{p} \beta_{i} \Delta y_{t-i+1}+\varepsilon_{t} \ldots \ldots \ldots \ldots . .(9) \\
\Delta y_{t}= & a_{0}+\delta y_{t-1}+\sum_{i=2}^{p} \beta_{i} \Delta y_{t-i+1}+\varepsilon_{t} . .(10) \\
\Delta y_{t}= & a_{0}+\delta y_{t-1}+a_{2} t+\sum_{i=2}^{p} \beta_{i} \Delta y_{t-i+1}+ \\
& \varepsilon_{t} \ldots \ldots \ldots \ldots \ldots \ldots \ldots \ldots \ldots \ldots \ldots \ldots \ldots . .(11
\end{aligned}
$$

Berdasarkan persamaan (9), (10), dan (11), maka disusunlah uji hipotesis sebagai berikut:

$\mathrm{H}_{0}: \delta=0$; ada akar-akar unit (tidak stasioner)

$\mathrm{H}_{1}: \quad \delta<0$; tidak ada akar-akar unit (stasioner)

Kriteria penolakan hipotesis nol $(\delta$ $=0)$ untuk ADF test adalah pada saat nilai test statistic pada $\delta$ berada di bawah nilai critical value, yang artinya data yang diuji bersifat stasioner. Pada penelitian ini, ADF test digunakan untuk menentukan order of integration dari suatu series. Dari beberapa model ADF test yang ada, penelitian ini memilih model yang memasukkan intersep di dalam proses uji akar unitnya.

\section{Gregory and Hansen Test}


Pada saat terdapat variabel yang tidak stasioner di level, namun stasioner di first difference, maka sebaiknya dilakukan uji kointegrasi. Uji kointegrasi dilakukan untuk mengetahui apakah kombinasi linear dari variabelvariabel di dalam model berkonvergensi ke keseimbangan atau tidak. Dengan kata lain, uji kointegrasi merupakan sebuah uji yang dilakukan untuk menemukan hubungan atau keseimbangan jangka panjang antar variabel-variabel yang terlibat. Syarat untuk mencapai keseimbangan jangka panjang adalah nilai galat harus berfluktuasi di sekitar angka nol. Dengan kata lain, galat tersebut harus stasioner.

Uji kointegrasi yang paling sering digunakan di dalam penelitian adalah Johansen and Juselius Cointegration Test serta Engle Granger Cointegration Test. Namun, pada saat suatu model yang mempertimbangkan keberadaan structural breaks, maka uji kointegrasi yang lebih tepat untuk diterapkan dalam analisis adalah Gregory and Hansen Test.

Gregory and Hansen Test merupakan uji kointegrasi yang dikembangkan oleh Gregory dan Hansen di tahun 1996. Uji kointegrasi ini sudah memperhitungkan structural breaks di dalam modelnya. Gregory and Hansen $\left(1996^{\mathrm{a}}\right)$ mempertimbangkan tiga model alternatif dalam uji kointegrasi-nya, yaitu (1) level shift (C), dimana pada model ini diasumsikan intersepnya bergeser, (2) level shift with trend $(\mathrm{C} / \mathrm{T})$, pada model ini intersep bergeser dan terdapat time trend di dalam model tersebut, dan (3) regime shift $(\mathrm{C} / \mathrm{S})$, pada model ini, bukan hanya pergeseran intersep yang dipertimbang-kan dalam uji kointegrasi, namun juga pergeseran dari slope.

Tidak lama kemudian, Gregory dan Hansen (1996 ${ }^{\mathrm{b}}$ ) mempertimbangkan model tambahan, yaitu regime and trend shift $(\mathrm{C} / \mathrm{S} / \mathrm{T})$, dimana dalam model tersebut mempertimbangkan pergeseran intersep dan slope serta memasukkan time trend ke dalam proses analisisnya. Berikut adalah beberapa persamaan untuk keempat model tersebut.

Model 1: Level shift

$y_{1 t}=\mu_{1}+\mu_{2} \varphi_{t \tau}+\alpha^{T} y_{2 t}+e_{t}$

Model 2: Level shift with trend $(\mathrm{C} / \mathrm{T})$

$y_{1 t}=\mu_{1}+\mu_{2} \varphi_{t \tau}+\beta t+\alpha^{T} y_{2 t}+e_{t} \cdots$

Model 3: Regime shift (C/S)

$y_{1 t}=\mu_{1}+\mu_{2} \varphi_{t \tau}+\alpha_{1}^{T} y_{2 t}+\alpha_{2}^{T} y_{2 t} \varphi_{t \tau}+e_{t}$

Model 4: Regime and trend shift (C/S/T)

$y_{1 t}=\mu_{1}+\mu_{2} \varphi_{t \tau}+\beta_{1} t+\beta_{2} t \varphi_{t \tau}+\alpha_{1}^{T} y_{2 t}+$

$\alpha_{2}^{T} y_{2 t} \varphi_{t \tau}+e_{t}$

Dalam penelitian ini, model yang akan digunakan dalam analisis kointegrasi adalah cointegration with regime shift model. Sehingga, uji kointegrasi akan dilakukan dengan mempertimbangkan keberadaan slope dan intersep di dalam proses analisis. Kriteria pengambilan keputusan dalam GH test, yakni hipotesis nol (no cointegration) ditolak apabila nilai uji statistik berada di bawah nilai critical value.

\section{State Space Model}

Penyebab regime shift dapat diidentifikasi dengan merumumuskan state space model. State space model dapat merepresentasikan variabel yang tidak teramati untuk dapat masuk ke dalam model yang diestimasi (Suwedayana et.al., 2016). Oleh karena itu, analisis ini dapat mengurangi unsur ketidakpastian dalam sebuah peramalan. Dalam penelitian ini, state space model diterapkan untuk mengestimasi fungsi jangka panjang pada fungsi permintaan uang dan mempelajari evolusi dari 
koefisien regresi menggunakan teknik Kalman filter. State space model yang menggunakan teknik Kalman filter dalam proses pendugaannya dapat disebut pula dengan model Time Varying Parameter (TVP). Model TVP mengestimasi perubahan suatu parameter yang sifatnya time variant (Setiawan, 2011). TVP model akan menunjukkan ada tidaknya perubahan parameter serta periode waktunya. Secara spesifik, model TVP dapat ditunjukkan oleh persamaan perhitungan dan state equations di bawah ini.

$m_{t}=Z^{\prime \phi_{t}}+\varepsilon_{t} ; \varepsilon_{t} \sim N\left(0, \sigma^{2}\right)$

$\left.\phi_{t}=A \phi_{t-1}+\eta_{t}, \eta_{t} \sim N(0, Q) \ldots . .17\right)$

dimana $\mathrm{Z}$ adalah vektor yang mengandung variabel penjelas pada model penelitian dan juga constant term, $\phi$ adalah vektor parameter, A adalah transition matrix, $\varepsilon$ dan $\eta$ adalah normally distributed noise terms, dan $\mathrm{Q}$ adalah diagonal covariance matrix. Hal tersebut diasumsikan bahwa dua noise terms dalam persamaan di atas tidak berkorelasi dan initial state vector terdistribusi secara normal, $\phi_{0} \sim N\left(\mu_{0}, \sum_{0}\right)$. Selain itu, $\phi_{\mathrm{t}}$ mengikuti multivariate random walk dengan meletakkan A=I, dimana I adalah matriks identitas (El-Shazly, 2016).

\section{HASIL DAN PEMBAHASAN}

\section{Uji Akar Unit}

Dalam penelitian ini, analisis univariat dengan melakukan uji akar unit dilakukan untuk menentukan break date dan order of integration dari masing-masing variabel di dalam model. Uji akar unit merupakan uji mendasar pada saat dilakukan analisis dengan menggunakan data time series. Penentuan break date dilakukan berdasarkan Zivot and Andrews Test, dimana uji akar unit tersebut di dalam proses analisisnya sudah mempertimbangkan keberadaan breaks. Sementara itu, untuk menentukan order of integration dari setiap variabel, uji yang digunakan adalah Augmented Dickey Fuller Test (ADF Test).

Pada Zivot and Andrews Test (ZA test), model yang digunakan adalah model $\mathrm{C}$, seperti yang ditunjukkan pada persamaan (4). Model C dalam ZA test telah memasukkan dummy slope dan dummy intercept ke dalam persamaan regresinya. Pengujian ini dilakukan dengan trimming data sebesar $15 \%$ dan pada maximum lag 4. Trimming data dapat bermanfaat pada saat menghadapi analisis statistik yang sensitif terhadap outlier. Pada Tabel 1 dapat dilihat hasil uji akar unit dengan menggunakan ZA Test. Pada ZA test, hasil menunjukkan bahwa variabel-variabel yang stasioner setelah mempertimbangkan keberadaan breaks diantaranya adalah variabel M1, pendapatan, suku bunga domestik, nilai tukar, dan inflasi. Sebaliknya, variabel M2 dan suku bunga luar negeri tidak stasioner pada level. 
Tabel 1 Hasil Uji Akar Unit dengan Zivot and Andrews Test (single break)

\begin{tabular}{lrrrrrrl}
\hline \multirow{2}{*}{ Variabel } & \multicolumn{7}{c}{ Zivot and Andrews test } \\
\cline { 2 - 8 } & \multicolumn{1}{c}{$\phi$} & $\mu$ & $\beta$ & $\Theta$ & $\gamma$ & $\begin{array}{c}\text { Lag } \\
\text { Length }\end{array}$ & $\begin{array}{l}\text { Break } \\
\text { point }\end{array}$ \\
\hline (Log) levels & & & & & & \\
$m l$ & $-0,733$ & 3,301 & 0,014 & 0,067 & $-0,003$ & 4 & $1998: \mathrm{Q} 1$ \\
& $(-5,988)^{*}$ & $(6,032)$ & $(5,479)$ & $(4,389)$ & $(-2,238)$ & & \\
& $-0,322$ & 1,651 & 0,008 & 0,038 & $-0,004$ & 0 & $1998: \mathrm{Q} 1$ \\
$y$ & $(-5,093)$ & $(5,154)$ & $(4,918)$ & $(3,156)$ & $(-4,194)$ & & \\
& $-0,439$ & 2,612 & 0,003 & $-0,054$ & $-0,000$ & 4 & $1998: \mathrm{Q} 1$ \\
$i^{d}$ & $(-8,338)^{*}$ & $(8,377)$ & $(4,631)$ & $(-6,982)$ & $(-0,453)$ & & \\
& $-0,253$ & 0,086 & 0,465 & $-7,573$ & $-0,494$ & 1 & $1999: \mathrm{Q} 1$ \\
$i^{f}$ & $(-6,920)^{*}$ & $(0,090)$ & $(6,245)$ & $(-6,987)$ & $(-6,178)$ & & \\
& $-0,151$ & 1,126 & $-0,018$ & 0,429 & $-0,004$ & 4 & $2004: \mathrm{Q} 4$ \\
$q$ & $(-4,484)$ & $(4,161)$ & $(-3,002)$ & $(2,205)$ & $(-0,614)$ & & \\
& $-0,754$ & 1,560 & 0,001 & $-0,188$ & 0,002 & 3 & $1997: \mathrm{Q} 4$ \\
$\pi$ & $(-8,235)^{*}$ & $(8,192)$ & $(0,604)$ & $(-6,631)$ & $(0,913)$ & & \\
& $-0,372$ & $-0,975$ & 0,532 & $-9,602$ & $-0,564$ & 1 & $2000: \mathrm{Q} 1$ \\
\hline
\end{tabular}

Critical values for test statistic

$99 \% \quad-5,57$

$95 \%-5,08$

$90 \% \quad-4,82$

Keterangan:

*berbeda nyata nyata $(\mathrm{P}<0,01)$

Dari hasil analisis tersebut, dihasilkan beberapa breaks di periodeperiode tertentu. Breaks terjadi karena adanya guncangan ekonomi, seperti krisis, ataupun peristiwa ekonomi lainnya, baik di dalam negeri maupun di luar negeri yang dapat berimbas terhadap perekonomian Indonesia. Secara umum, dari hasil ZA test dapat kita ketahui bahwa breaks date terjadi pada tahun 1997 kuartal akhir hingga tahun 1999 kuartal pertama.

Periode breaks date tersebut merupakan periode saat terjadinya krisis Asia, yang diawali oleh terdevaluasinya mata uang Baht Thailand dan memiliki efek domino pada negara-negara di Asia Timur dan Asia Tenggara, termasuk Indonesia. Sementara itu, breaks juga muncul pada periode tahun 2000 kuartal pertama yang merupakan puncak dari terjadinya peristiwa dot-com bubble, dimana para investor di pasar saham berlomba-lomba mengucurkan dananya ke perusahaan-perusahaan dot-com yang bergerak di bidang internet. Namun, pada musim tahun 2000 terdapat gelombang penjualan saham internet secara tiba-tiba yang menjadikan pasar saham turun cukup jauh (Wheale dan Amin, 2010). Pada tahun 2004 juga terdapat breaks yang diperoleh dari variabel suku bunga luar negeri yang diduga merupakan dampak dari kebijakan The Fed yang meningkatkan suku bunganya sejak Juli 2004 (Bank Indonesia, 2013).

Berdasarkan hasil ZA test, peristiwa maupun kebijakan ekonomi yang tercermin dari periode breaks dan telah memengaruhi variabel-variabel makroekonomi Indonesia berasal dari peristiwa-peristiwa ekonomi di luar Indonesia. Dengan kata lain, perekonomian Indonesia sangat rentan terhadap guncangan eksternal.

Pada tahap selanjutnya, untuk menentukan order of integration dari setiap variabel, maka dilakukan ADF test yang melibatkan intersep dalam 
persamaan regresinya. Maximum lag yang ditetapkan dalam pengujian ini, yaitu pada maximum lag 4, sama halnya dengan uji pada ZA test. Hasil dari ADF test dapat dilihat pada Tabel 2. Hasil menunjukkan bahwa diperoleh hasil dimana hanya terdapat satu variabel yang stasioner pada level, yaitu variabel inflasi. Sementara variabel lainnya seperti M1, M2, pendapatan, suku bunga domestik, suku bunga luar negeri, dan nilai tukar, tidak stasioner pada level, namun stasioner pada first difference.

Tabel 2 Hasil Uji Akar Unit dengan Augmented Dickey Fuller Test

\begin{tabular}{|c|c|c|c|c|c|}
\hline \multirow[b]{2}{*}{ Variabel } & \multicolumn{2}{|c|}{ ADF test in level } & \multirow[b]{2}{*}{ Variabel } & \multicolumn{2}{|c|}{ ADF test in first difference } \\
\hline & t-statistic & $\begin{array}{c}\text { Lag } \\
\text { Length }\end{array}$ & & $t$-statistic & Lag Length \\
\hline$m 1$ & $-1,590$ & 4 & $\Delta m 1$ & $-4,405^{*}$ & 3 \\
\hline$m 2$ & $-2,250$ & 0 & $\Delta m 2$ & $-8,131 *$ & 0 \\
\hline$y$ & 0,013 & 4 & $\Delta y$ & $-3,614 *$ & 4 \\
\hline$i^{d}$ & $-3,143$ & 1 & $\Delta i^{d}$ & $-4,939 *$ & 0 \\
\hline$i^{f}$ & $-1,514$ & 1 & $\Delta i^{f}$ & $-4,770 *$ & 0 \\
\hline$q$ & $-2,350$ & 3 & $\Delta q$ & $-6,436 *$ & 2 \\
\hline$\pi$ & $-6,154 *$ & 1 & $\Delta \pi$ & $-6,829 *$ & 2 \\
\hline \multicolumn{6}{|c|}{ Critical values for test statistic } \\
\hline & $99 \%$ & & & $-3,516$ & \\
\hline & $95 \%$ & & & $-2,899$ & \\
\hline & $90 \%$ & & & $-2,587$ & \\
\hline
\end{tabular}

Keterangan:

**berbeda nyata nyata $(\mathrm{P}<0,01)$

\section{Pointegrasi dan Perubahan Struktural}

Seperti yang telah disampaikan sebelumnya, bahwa pada suatu model yang menggunakan data time series, parameter yang diestimasi dapat berubah dari waktu ke waktu. Salah satu pendekatan untuk mendeteksi perubahan struktural pada titik waktu tertentu adalah dengan menguji apakah hubungan kointegrasi diantara variabel di dalam model bergantung pada waktu. Selain itu, berdasarkan hasil dari uji akar unit yang telah dilakukan sebelumnya, diketahui pula bahwa hampir seluruh variabel yang terdapat di dalam model stasioner pada first difference. Oleh karena itu, penting kiranya untuk melakukan uji kointegrasi. Gregory and Hansen Test (GH Test) mengadopsi pendekatan tersebut yang juga merupakan perluasan analisis multivariat dari ZA test yang mempertimbangkan faktor keberadaan structural break.

Model regime shift dipilih dalam $\mathrm{GH}$ test untuk menentukan hubungan kointegrasi diantara variabel-variabel yang terlibat dalam penelitian. Model regime shift merupakan model yang memasukkan pergeseran intersep dan slope dalam persamaan regresinya, seperti yang ditunjukkan dalam persamaan (14). Break point ditentukan secara endogen sebagai titik dimana nilai ADF statistic diminimumkan dan trimming sebesar $15 \%(\tau=0,15)$. 
Tabel 3 Hasil Uji Kointegrasi dengan Gregory and Hansen Test

\begin{tabular}{llll}
\hline \multirow{2}{*}{ Variabel } & \multicolumn{3}{c}{ GH test result } \\
\cline { 2 - 4 } & t-statistic & Lag Length & Break point \\
\hline M1 & $-7,03^{* * *}$ & 0 & $1997:$ Q3 \\
M2 & $-5,96^{*}$ & 0 & $2004: \mathrm{Q} 3$ \\
Critical values for test & statistic & & \\
$99 \%$ & $-7,40$ & & \\
$95 \%$ & $-6,89$ & & \\
$90 \%$ & $-6,66$ & & \\
\hline Keterangan: & & \\
$* *$ berbeda nyata nyata $(\mathrm{P}<0,01)$ & & \\
$* * *$ berbeda nyata nyata $(\mathrm{P}<0,05)$ & & \\
$* * * *$ berbeda nyata nyata $(\mathrm{P}<0,10)$ &
\end{tabular}

Tabel 3 menunjukkan hasil uji kointegrasi model M1 dan M2. Pada model M1 diperoleh hasil bahwa hipotesis nol (no cointegration) tidak ditolak pada taraf nyata $10 \%$. Hipotesis nol pada M1 dan M2 diterima pada taraf nyata $1 \%$. Dengan demikian, nilai statistik GH memberikan bukti bahwa parameter tidak konstan dan terjadi regime shift pada kedua model tersebut. Estimasi break date berkisar pada tahun 1997 dan 2004. Break pada tahun 1997 terjadi karena peristiwa krisis ekonomi di wilayah Asia Timur. Krisis ini berawal dari krisis yang terjadi di Thailand dan menyebabkan mata uang Baht terdevaluasi.

Selanjutnya, krisis ini menimbulkan contagion effect terhadap negaranegara di Asia, termasuk Indonesia. Krisis 1997 telah berdampak pada terdepresiasinya nilai rupiah dan hargaharga barang di Indonesia melambung tinggi. Di sisi lain, break terjadi pada tahun 2004 kuartal ketiga yang muncul akibat dari adanya kenaikan suku bunga The Fed yang pada akhirnya berimbas pula pada kenaikan suku bunga di dalam negeri. Kedua peristiwa tersebut merupakan guncangan eksternal yang berdampak besar pada kondisi ekonomi Indonesia, khususnya dalam hal ini adalah permintaan uang.

\section{Time Varrying Parameter}

Dari hasil uji kointegrasi dengan menggunakan Gregory and Hansen test diperoleh hasil bahwa terjadi ketidakseimbangan fungsi permintaan uang dalam jangka panjang akibat dari perubahan struktural. Perubahan struktural tersebut dibuktikan dengan keberadaan regime shift dalam fungsi permintaan uang. Salah satu penyebab terjadinya regime shifts dapat diidentifikasi dengan menggunakan time varying parameter model yang merupakan bagian dari state space model. Hasil dari metode ini menghasilkan grafik evolusi dari koefisien regresi dengan menerapkan pula teknik Kalman Filter.

Berdasarkan hasil analisis tersebut diperoleh hasil dimana untuk parameter faktor internasional, yaitu suku bunga luar negeri dan nilai tukar menghasilkan tanda negatif, baik pada model $m_{1}$ maupun $m_{2}$. Tanda negatif pada parameter nilai tukar tersebut mencerminkan adanya dampak currency substitution dan portfolio adjustment dalam model permintaan uang di Indonesia. Di sisi lain, untuk parameter pendapatan, suku bunga domestik, dan inflasi, tanda koefisien yang diperoleh adalah positif. 
Tabel 4 Hasil Kalman Filter untuk Model M1

\begin{tabular}{ccccc}
\hline State Vector & Final State & Root MSE & z-Statistic & Prob. \\
\hline SV1 & 0,911560 & 0,057895 & 15,74505 & 0,0000 \\
SV2 & 0,041441 & 0,008133 & 5,095053 & 0,0000 \\
SV3 & $-0,001761$ & 0,008369 & $-0,210401$ & 0,8334 \\
SV4 & $-0,064242$ & 0,175486 & $-0,366082$ & 0,7143 \\
SV5 & 0,002715 & 0,002019 & 1,345172 & 0,1786 \\
\hline Log likelihood & 86,57991 & Akaike info criterion & $-2,061426$ \\
Parameters & 0 & Schwarz criterion & $-2,061426$ \\
Diffuse priors & 5 & Hannan-Quinn criter, & $-2,061426$ \\
\hline
\end{tabular}

Tabel 5 Hasil Kalman Filter untuk Model M2

\begin{tabular}{crcrr}
\hline State Vector & Final State & Root MSE & z-Statistic & Prob. \\
\hline SV1 & 1,039291 & 0,046198 & 22,49652 & 0,0000 \\
SV2 & 0,045607 & 0,006490 & 7,027051 & 0,0000 \\
SV3 & $-0,006903$ & 0,006678 & $-1,033676$ & 0,3013 \\
SV4 & $-0,161488$ & 0,140030 & $-1,153235$ & 0,2488 \\
SV5 & 0,000889 & 0,001611 & 0,551758 & 0,5811 \\
\hline Log likelihood & 104,4229 & Akaike info criterion & & $-2,486260$ \\
Parameters & 0 & Schwarz criterion & $-2,486260$ \\
Diffuse priors & 5 & Hannan-Quinn criter, & $-2,486260$ \\
\hline
\end{tabular}

Hasil utama yang diperoleh dari analisis ini adalah grafik dari plot evolusi koefisien regresi yang menunjukkan perubahan parameter dari waktu ke waktu. Pada gambar 2 dan 3 , dapat kita lihat plot dari evolusi state variable untuk nilai tukar selama periode penelitian. Ketidakstabilan awal pada koefisien yang diestimasi berkaitan dengan jumlah observasi yang kecil yang digunakan dalam recursive estimation pada prosedur awal analisis (El-Shazly, 2016). Ketidakstabilan parameter yang sangat terlihat berada pada koefisien untuk variabel nilai tukar pada periode sebelum 1998, yang sejalan dengan peristiwa krisis yang terjadi di Asia. Krisis Asia terjadi pada tahun 1997, yang diawali dengan terdevaluasinya mata uang Baht Thailand, dan berdampak pada terjadinya krisis nilai tukar di Indonesia. Sepanjang tahun 1998 mata uang rupiah terdepresiasi hingga $70 \%$, dan mengalami puncaknya pada bulan Juli 1998, dimana nilai rupiah per dollar mencapai Rp 14700 per US\$ (Karmeli dan Fatimah, 2008). 


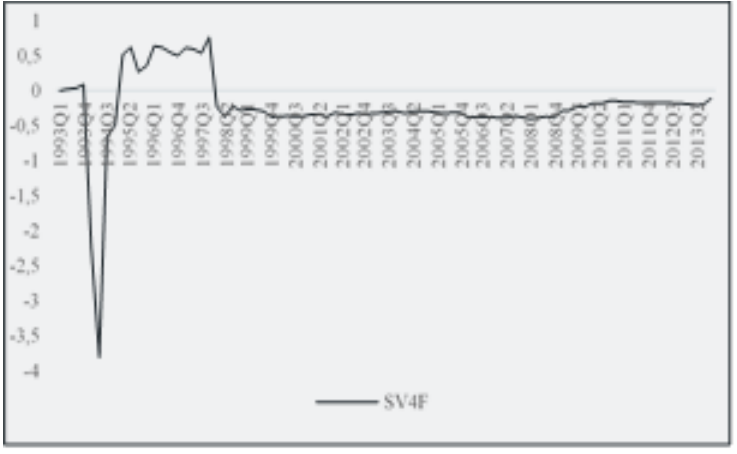

Gambar 2 Evolusi koefisien nilai tukar dalam model M1

Berdasarkan hasil tersebut, dapat kita ketahui bahwa nilai tukar merupakan salah satu sumber dari ketidakstabilan permintaan uang di Indonesia, baik untuk model $m_{l}$ maupun $m_{2}$. Nilai tukar sangat dipengaruhi oleh kondisi stabilitas ekonomi global. Sebagai negara dengan sistem perekonomian terbuka yang menganut sistem nilai tukar mengambang bebas (free floating exchange rate), Indonesia sangat rentan terhadap gangguan eksternal. Hal ini dikarenakan Indonesia masih memiliki ketergantungan yang tinggi terhadap sektor-sektor di luar negeri. Selain itu, dalam sistem nilai tukar mengambang bebas, nilai tukar menjadi lebih fluktuatif yang dapat menambah ketidakpastian dalam dunia usaha.

Sistem nilai tukar mengambang juga sangat dipengaruhi oleh kondisi pasar. Pergerakan nilai tukar di pasar sangat dipengaruhi oleh faktor fundamental dan non fundamental (Warjiyo dan Solikin, 2003). Faktor fundamental dapat dilihat dari variabelvariabel makro ekonomi, seperti pertumbuhan ekonomi, laju inflasi, kegiatan ekspor impor, dan sebagainya.

Di sisi lain, faktor non fundamental lebih tercermin dari sentimen pasar terhadap beberapa fenomena, diantaranya sosial politik,

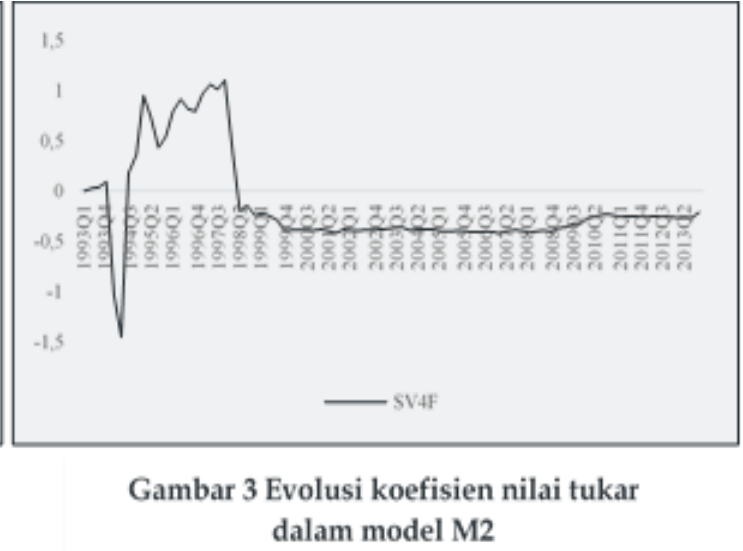

faktor psikologi para pelaku pasar dalam memperhitungkan informasi atau rumor yang beredar di masyarakat, yang akan berpengaruh terhadap perkembangan nilai tukar harian. Sementara itu, time path dari state variable lainnya di dalam model terlihat cukup stabil.

\section{KESIMPULAN}

Berdasarkan hasil ZA test dan GH test, dapat diketahui bahwa breaks yang terjadi secara umum akibat dari ketidakseimbangan yang terjadi dalam perekonomian global. Negara Indonesia merupakan negara dengan sistem perekonomian terbuka. Namun, dari segi perekonomian, Indonesia termasuk negara kecil, sehingga kondisi perekonomiannya sangat rentan terhadap guncangan eksternal. Oleh karena itu, kondisi perekonomian global akan sangat memengaruhi kondisi perekonomian Indonesia. Oleh karena itu, hasil dari state space model dengan teknik Kalman Filter juga memperkuat kondisi tersebut. Hasil menunjukkan bahwa penyebab dari perubahan struktural yang berdampak pada ketidakstabilan permintaan uang di Indonesia ada tiga variabel, diantaranya yaitu, suku bunga luar negeri, nilai tukar, dan inflasi. Namun, apabila 
dilihat dari grafik evolusi koefisien ketiga variabel tersebut, ketidakstabilan koefisien yang paling terlihat adalah pada nilai tukar.

Indonesia menganut sistem nilai tukar mengambang bebas (free floating exchange rate). Dengan sistem nilai tukar tersebut, nilai tukar rupiah akan sangat dipengaruhi oleh kondisi pasar valuta asing. Dengan demikian, pemerintah Indonesia, khususnya dalam hal ini otoritas moneter, perlu memperhatikan hal tersebut dengan cara memperkuat kestabilan perekonomian di Indonesia agar tida mudah terpengaruh oleh guncangan-guncangan eksternal.

\section{DAFTAR PUSTAKA}

Arango S, Nadiri MI. 1981. Demand for Money in Open Economies. Journal of Monetary Economics 7: 69-83.

BI (Bank Indonesia). 2013. Seni Kebijakan Moneter. Gerai Info Newsletter Bank Indonesia Edisi 40, Juli 2013, Tahun 4.

Dickey DA, Fuller WA. 1979. Distribution of the Estimators for Autoregressive Time Series with a Unit Root. Journal of The American Statistical Association 74 (366): 427-431.

Dreger C, Wolters J. 2010. Investigating M3 Money Demand in the Euro Area. Journal of International Money and Finance 29 : 111-122.

Dritsakis N. 2012. Structural Breaks, Cointegration and the Demand for Money in Greece. The IUP Journal of Applied Economics XI (3): 5-21.

El-Shazly A. 2016. Structural Breaks and Monetary Dynamics: A Time Series Analysis. Economic Modelling 53: 133-143.
Enders W. 2004. Applied Econometric Time Series. Second Edition. United States of America: John Wiley \& Sons, Inc.

Ericsson NR. 1998. Empirical Modelling of Money Demand. Empirical Economics 23: 295315.

Farhani S. 2012. Tests of Parameter Instability: Theoretical Study and Empirical Analysis on Two Types of Models (ARMA Model and Market Model). International Journal of Economics and Financial Issues 2 (3): 246-266.

Gregory A, Hansen B. 1996'a ResidualBased Tests for Cointegration in Models with Regime Shifts. Journal of Econometrics 70: 99126.

$.1996^{\mathrm{b}}$. Tests for Cointegration in Models with Regime and Trend Shifts. Oxford Bulletin of Economics and Statistics 58 (3).

Karmeli E, Fatimah S. 2008. Krisis Ekonomi Indonesia. Journal of Indonesian Applied Economics 2 (2): 164-173.

Narayan PK. 2007. Is money targeting an option for Bank Indonesia?. Journal of Asian Economics 18: 726-738.

Setiawan A. 2011. Inflation Targeting Framework dan Perubahan Respon Kebijakan Moneter. Tesis. Jakarta: Universitas Indonesia.

Suwedayana IPGDG, Sumarjaya IW, Sucipawati NL. 2016. Peramalan Jumlah Kunjungan Wisatawan Australia yang Berkunjung ke Bali Menggunakan Model Time Varying Parameter (TVP). EJurnal Matematika 5 (3): 117-125.

Warjiyo P, Solikin. 2003. Kebijakan Moneter di Indonesia. Seri Kebanksentralan Nomor 6, Pusat 
Pendidikan dan Studi Kebanksentralan. Bank Indonesia, Wheale RW, Amin LH. 2010. Bursting the dot.com "Bubble": A Case Study in Investor Behaviour. Technology Analysis \& Strategic Management 15 (1): 117-136.

Zivot E, Andrews DWK. 1992. Further Evidence on the Great Crash, the Oil-Price Shock, and the UnitRoot Hyphothesis. Journal of Business and Economic Statistics 10 (3): 251-270. 